\title{
Development of Test Instruments to Analyze Higher-Order Thinking Skills Through Science-Based Literacy Learning
}

\author{
Qisthi Fariyani ${ }^{1}$, Hamdan Hadi Kusuma ${ }^{2}$ \\ State Islamic University (UIN) Walisongo Semarang, Indonesia ${ }^{1,2}$ \\ qisthifariyani@walisongo.ac.id ${ }^{1}$, hamdanhk@walisongo.ac.id ${ }^{2}$
}

Received: August $12^{\text {th }}, 2020$. Revised: November $16^{\text {th }}, 2020$. Accepted: November $25^{\text {th }}, 2020$

\author{
Keywords : \\ Test Instruments; High Order \\ Thinking Skills; Pre-service \\ Physics Teacher; Sciece \\ Literacy; Simple Harmonic \\ Motion
}

\begin{abstract}
Higher-order thinking skills are essential skills for a preservice teacher to have. This study aims to develop the instrument and measure the higher-order thinking skills pre-service physics teacher UIN Walisongo Semarang with science literacy-based learning using the High Order Thinking Skills instrument. The data collection method used was a test, consisting of 20 selected questions with open reasons; structured interviews with lecturers and preservice physics teachers; and documentation to collect preservice physics teachers' data required for research. The test instrument developed by reacherchers and validated by expert in the field of evaluation and physics. The instrument developed was in the form of questions grids, test questions, answer keys, scoring and assessment guidelines, and guidelines for the interpretation of high order thinking skills. The results of product development obtained 14 test items representing four indicators on Simple Harmonic Motion material. The results showed that the higher-order thinking skills of pre-service physics teachers were in the poor category, with an average percentage of $39 \%$. The highest thinking skills are in the indicators determining the period and frequency of vibrations in simple harmonic motion that is in the good category with a percentage of $60.8 \%$. The lowest thinking skills are on the indicator of analyzing energy in simple harmonic moving objects, which are in the inferior category with a percentage of $12.8 \%$. The results of the research show that the higher-order thinking skills of pre-service physics teachers are still low, so that lecturers need to follow up to improve higher-order thinking skills of pre-service physics teachers UIN Walisongo Semarang.
\end{abstract}

\section{INTRODUCTION}

Physics is a subject that requires high order thinking skills to solve problems [1]. Learning Physics is not just doing calculations using formulas, but understanding, analyzing, and applying concepts to solve 
problems. Therefore, learning Physics requires not only low order thinking but also high order thinking skills [2]. Someone is said to have higher-order thinking skills if they can apply and manipulate knowledge to solve problems [3].

All this time, learning in school and college has not been much-directing students to improve higherorder thinking skills [4]. As a result, students are not trained to think at a high level and are only accustomed to solving problems at cognitive levels $\mathrm{C} 1, \mathrm{C} 2$, and $\mathrm{C} 3$. Higher-order thinking skills prevent students from memorizing and are more demanding to analyze, interpret, reason, synthesize, and evaluate [5]. Based on the teaching experience at the Physics Education Study Program, UIN Walisongo Semarang, students still have difficulty in solving problems that require analysis, evaluation, and creation. The ability of students is only in the realm of remembering, restating, and referring directly. This indicates that students' high order thinking skills are still low. Research on thinking skills in schools shows students' high order thinking skills are also still low. The results of the study by Kurniati et al. showed that $40 \%$ of students scattered in several Jember Regency Junior High Schools did not have excellent analytical, evaluation, creative, logic and reasoning skills in solving all problems [6]. Zulfiani et.al have conducted a study to determine the profile of students' higher order thinking skills using the Science Adaptive Assessment Tool application. The results of this study indicate that students' highorder thinking skills in the field of physics are in the lower category with an average score of 21.28 from a maximum score of 70 [7].

Graduates of the Physics Education Study Program are expected to become reliable teachers. The teacher must be able to create a learning atmosphere that encourages students to think and provides opportunities for students to construct concepts [8]. This will not happen if pre-service teachers do not have high order thinking skills to solve Physics problems. The thinking skills of a teacher will influence the process of understanding students' material [9]. One way to improve higher-order thinking skills is by learning scientific literacy based. The results of previous studies indicate that the increase in scientific literacy skills will be balanced with an increase in higher-order thinking skills [10]. Through science literacy-based learning, students are expected to be able to obtain new knowledge, identify problems, explain scientific phenomena, and draw conclusions [11]. This research develops and tests the preservice physics teachers' higher-order thinking skills test instruments taught with science literacy-based learning. This is done so that students are trained to think at a high level before working on problems and tested at higher-order thinking skills.

Pre-service physics teachers' higher-order thinking skills are fundamental to know. Lecturers can plan appropriate follow-up after knowing the level of thinking of their students. To date, there has never been developed a test instrument to test the high order thinking skills of pre-service physics teachers UIN Walisongo Semarang. The ethical questions to test higher-order thinking skills must be able to describe the ability to connect concepts, interpret, solve problems, choose strategies to solve problems, find new methods, argue, and make the right decisions [12]. Test questions can be in the form of multiple-choice, essay, or reasoned multiple choice.

Several researchers have previously developed instruments to analyze higher order thinking skills. Tiruneh et.al developed higher order thinking instruments, especially critical thinking skills in electricity and magnetism, namely CTEM in the form of multiple choice questions [13]. Batlolona et al. developed a one-tier diagnostic test instrument in the form of essay to investigate students' creative thinking skills in the elasticity material. The results of these studies indicate that PBL can improve students' creative thinking skills [14].

This study develops higher order thinking skills instruments that are different from what previous researchers have done. The test questions developed are in the form of multiple-choice with open reasons, which require pre-service physics teachers to choose answers and give reasons in answering questions. This form can explore pre-service physics teachers' thinking flow in solving problems. Lecturers can know the mindset of pre-service physics teachers from the reasons given in answering questions and can map the level of pre-service physics teacher thinking. The form of multiple-choice 
questions with open reasons also minimizes pre-service physics teachers who answer correctly because of the luck factor (without understanding the concept) as is often the case with multiple-choice questions.

This study aims to develop a test instrument to measure the higher-order thinking skills of pre-service physics teacher UIN Walisongo Semarang with science literacy-based learning. The instrument developed was tested for validity, reliability, and item characteristics before it was used to measure the higher-order thinking skills of pre-service physics teachers. The results of this study are expected to help lecturers and other educators to be able to analyze higher order thinking skills. Thus, lecturers can determine improvements appropriately, both in terms of students and materials that need improvement, as well as the methods used.

\section{METHOD}

\section{Research Design}

This research uses an R\&D approach, conducted using research and development procedures by Gall et al. [15]. The resulting product is an instrument to measure higher-order thinking skills, especially for pre-service physics teacher UIN Walisongo Semarang.

\section{Population and Sample}

The population of this study were all students of Physics Education Department at UIN Walisongo Semarang. The sampling technique was purposive sampling. This sampling technique has provisions, namely students who have taken Basic Physics 1 courses. The sample used is 36 students for preliminary field testing and 65 students for main field testing.

\section{Research Instruments}

The research instruments used were test instruments, questionnaires, and interview sheets. The questionnaire was given to the validator to assess the feasibility of the product being developed.

\section{Research Procedures}

The research begins with a needs analysis which is carried out through interviews with lecturers and learning observations. Furthermore, the determination of research objectives and the design and manufacture of products in the form of higher order thinking skills test instruments were carried out. The product that has been developed is further validated by two experts in the field of physics and evaluation. Products that have been declared valid are then tested on a small scale to determine their reliability, difficulty level, and differentiation power. The test results are used as consideration for revising the product. The revised product was then tested on a wide scale to determine the profile of higher order thinking skills of preservice physics teacher UIN Walisongo Semarang.

\section{Data Collection Techniques}

Research data were collected through the test, interview and documentation methods. Developed test instruments in the form of indicator questions, test question cards, answer keys, answer sheets, and scoring guidelines. The test question is in reasoned multiple-choice, consist of five answer choices with one answer key and opened reason that must be answered by pre-service physics teacher UIN Walisongo Semarang. Indicators of the higher-order thinking skills test developed by researchers and validated by two experts in physics anda evaluate are shown in Table 1. Interviews were conducted with lecturers at the beginning of the study for needs analysis, and at the end to find out the lecturer's opinion about the instruments developed. Documentation is done to collect data related to research, such as a list of names and a recap of student grades.

\section{Data Analysis Techniques}

The validity of the developed test questions is done by testing the validity of the items. Reliability is determined using the Cronbach Alpha formula. The developed test questions also analyzed the level of difficulty and the different power of the questions. Analysis of higher-order thinking skills is done by 
categorizing pre-service physics teacher grades, according to Table 2 [16].

Table 1. Indicators of Higher Order Thinking Skills Test

\begin{tabular}{lcc}
\hline \multicolumn{1}{c}{ Indicator } & Stage & Question Number \\
\hline $\begin{array}{l}\text { Analyze the forces acting on simple harmonic } \\
\text { motion and the magnitudes that affect it }\end{array}$ & $\begin{array}{c}\text { Analyze } \\
\text { Evaluate } \\
\text { Create }\end{array}$ & 2,3 \\
\hline $\begin{array}{l}\text { Analyze discourse and harmonic motion equations } \\
\text { on springs and swings to determine the period and } \\
\text { frequency of vibrations }\end{array}$ & Analyze & 1 \\
\hline $\begin{array}{l}\text { Analyze experimental data to determine the } \\
\text { deviation equations in simple harmonic motion }\end{array}$ & Create & 7,8 \\
and the magnitudes that affect them & Analyze & 5,6 \\
\hline $\begin{array}{l}\text { Analyze energy in simple harmonic moving } \\
\text { objects }\end{array}$ & Create & 10 \\
\hline
\end{tabular}

Table 2. Category of Higher Order Thinking Skills

\begin{tabular}{cc}
\hline Score & Category \\
\hline $80 \leq N \leq 100$ & Very Good \\
$60 \leq N<80$ & Good \\
$40 \leq N<60$ & Moderate \\
$20 \leq N<40$ & Less \\
$N<20$ & Very Less \\
\hline
\end{tabular}

\section{RESULTS AND DISCUSSIONS}

The instrument for measuring higher-order thinking skills is an essential part of the assessment instrument to develop. Mohamed \& Lebar states that to improve the quality of international education, examinations and assessments are focused on higher-order thinking skills [17]. The results of the development of instruments in this study were in the form of questions, work instructions, test questions, answer keys, scoring and assessment guidelines, and guidelines for interpretation of higher-order thinking skills. The test questions that have been developed are then tested for validity, reliability, level of difficulty, and different power before they are used to measure the high-level thinking skills of the pre-service physics teacher students of UIN Walisongo Semarang.

\section{Validity Test}

The results of the item validity test showed 14 of the 20 questions developed were included in the valid category. The results of testing the validity of items are presented in Table 3. The development of a higher-order thinking skills test instrument was also carried out by Serevina et al. on Static Fluid material for the high school level. The development of the instrument resulted in 30 valid questions out of 35 items tested [18]. Validity is related to the level of confidence of the instrument to be used as a measurement tool. A valid test instrument will be able to measure the variables to be measured accurately.

Table 3. Results of Analysis of Validity Test

\begin{tabular}{cccccc}
\hline $\begin{array}{l}\text { Question } \\
\text { Number }\end{array}$ & $\boldsymbol{\Sigma} \boldsymbol{x}$ & $\boldsymbol{\Sigma} \boldsymbol{x}^{\mathbf{2}}$ & $\boldsymbol{\Sigma} \boldsymbol{x y}$ & $\boldsymbol{r}_{\boldsymbol{x} \boldsymbol{y}}$ & Criteria \\
\hline 1 & 87 & 253 & 1724 & 0.46 & valid \\
2 & 55 & 275 & 1580 & 0.75 & valid \\
3 & 25 & 25 & 459 & 0.09 & not valid \\
4 & 29 & 55 & 717 & 0.61 & valid \\
5 & 23 & 39 & 515 & 0.37 & valid \\
6 & 34 & 56 & 630 & 0.09 & not valid
\end{tabular}


Development of Test Instruments to Analyze Higher-Order Thinking Skills... Qisthi Fariyani, Hamdan Hadi Kusuma

\begin{tabular}{cccccc}
\hline $\begin{array}{c}\text { Question } \\
\text { Number }\end{array}$ & $\boldsymbol{\Sigma} \boldsymbol{x}$ & $\boldsymbol{\Sigma} \boldsymbol{x}^{\mathbf{2}}$ & $\boldsymbol{\Sigma} \boldsymbol{x y}$ & $\boldsymbol{r}_{\boldsymbol{x y}}$ & Criteria \\
\hline 7 & 72 & 264 & 1651 & 0.58 & valid \\
8 & 82 & 290 & 1745 & 0.48 & valid \\
9 & 37 & 157 & 1075 & 0.66 & valid \\
10 & 38 & 92 & 915 & 0.57 & valid \\
11 & 15 & 25 & 377 & 0.44 & valid \\
12 & 10 & 32 & 231 & 0.17 & not valid \\
13 & 22 & 34 & 482 & 0.34 & valid \\
14 & 15 & 15 & 274 & 0.04 & not valid \\
15 & 11 & 35 & 159 & 0.11 & not valid \\
16 & 23 & 45 & 649 & 0.75 & valid \\
17 & 9 & 9 & 235 & 0.49 & valid \\
18 & 25 & 45 & 649 & 0.67 & valid \\
19 & 26 & 36 & 660 & 0.82 & valid \\
20 & 3 & 3 & 66 & 0.13 & not valid \\
\hline
\end{tabular}

Reliability Test

Instrument reliability is related to the level of an ability to provide measurement results. An instrument has high reliability if it allows for consistent measurement results, even though it is done at different times. The test results of the reliability of the test questions showed the value of $r$ count $=0.75$ and $r$ table $=0.329$ with a significance level of $5 \%$. Based on the results of the analysis, the test questions developed can be declared reliable.

Level of Difficulty

The level of difficulty test is done to find out the categories of questions, including easy, moderate, or difficult. Results of testing the level of difficulty of the questions are presented in Table 4.

Table 4. Difficulty Level Analysis Results

\begin{tabular}{cccc}
\hline $\begin{array}{c}\text { Question } \\
\text { Number }\end{array}$ & Mean & Difficulty Level & Criteria \\
\hline 1 & 2.42 & 0.48 & Moderate \\
2 & 1.53 & 0.31 & Moderate \\
3 & 0.69 & 0.69 & Moderate \\
4 & 0.81 & 0.27 & Difficult \\
5 & 0.64 & 0.21 & Difficult \\
6 & 0.94 & 0.47 & Moderate \\
7 & 2.00 & 0.40 & Moderate \\
8 & 2.28 & 0.46 & Moderate \\
9 & 1.03 & 0.21 & Difficult \\
10 & 1.06 & 0.21 & Difficult \\
11 & 0.42 & 0.21 & Difficult \\
12 & 0.28 & 0.06 & Difficult \\
13 & 0.61 & 0.31 & Moderate \\
14 & 0.42 & 0.42 & Moderate \\
15 & 0.31 & 0.06 & Difficult \\
16 & 0.64 & 0.32 & Moderate \\
17 & 0.25 & 0.25 & Difficult \\
18 & 0.69 & 0.35 & Moderate \\
19 & 0.72 & 0.36 & Moderate \\
20 & 0.08 & 0.08 & Difficult \\
\hline
\end{tabular}




\section{Different Power}

Different matter of power is needed to determine the ability of the question in distinguishing smart and less smart students. The results of different power analysis can be seen in Table 5 .

Table 5. Results of Different Power Analysis

\begin{tabular}{cccc}
\hline Question Number & MA & MB & DP \\
\hline 1 & 0.60 & 0.37 & 0.23 \\
2 & 0.61 & 0.00 & 0.61 \\
3 & 0.14 & 0.13 & 0.01 \\
4 & 0.28 & 0.04 & 0.23 \\
5 & 0.31 & 0.07 & 0.25 \\
6 & 0.50 & 0.44 & 0.06 \\
7 & 0.59 & 0.21 & 0.38 \\
8 & 0.57 & 0.34 & 0.22 \\
9 & 0.38 & 0.03 & 0.34 \\
10 & 0.34 & 0.08 & 0.27 \\
11 & 0.33 & 0.03 & 0.30 \\
12 & 0.08 & 0.03 & 0.04 \\
13 & 0.42 & 0.08 & 0.34 \\
14 & 0.39 & 0.09 & 0.30 \\
15 & 0.07 & 0.06 & 0.01 \\
16 & 0.61 & 0.01 & 0.60 \\
17 & 0.44 & 0.01 & 0.43 \\
18 & 0.67 & 0.01 & 0.66 \\
19 & 0.64 & 0.03 & 0.61 \\
20 & 0.02 & 0.01 & 0.01 \\
\hline
\end{tabular}

Questions that are tested in the field test are questions that meet valid criteria, and the different power is not discarded. The number of questions that are feasible to use based on analysis is 14 items.

\section{Analysis of Higher-Order Thinking Skills for Pre-service Physics Teachers}

Main field tests were conducted on 65 pre-service physics teacher UIN Walisongo Semarang. Test results were analyzed to find out the overall high-level thinking skills of pre-service physics teachers as a whole and each question indicator. The results of higher-order thinking skills of pre-service physics teachers as a whole are presented in Figure 1.

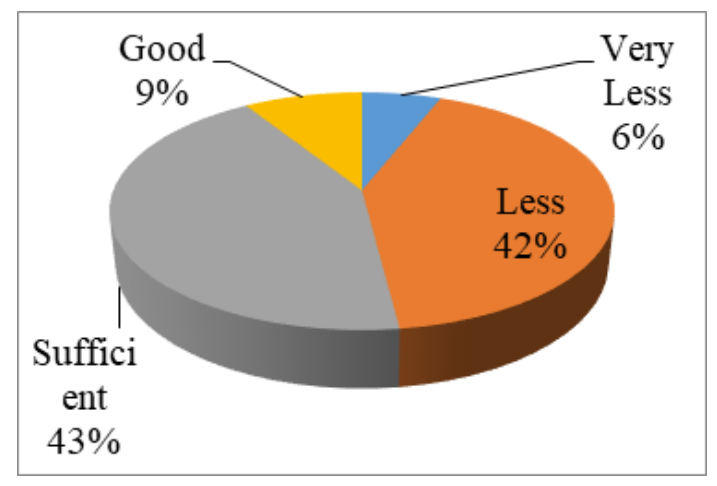

Fig 1. Higher-Order Thinking Skills of Pre-service Physics Teachers

Figure 1 shows that the higher-order thinking skills of pre-service physics teachers are mostly in the less and sufficient categories. This result is in line with the research of Yee et al., who researched higherorder thinking skills in students. Yee et al. show that students have moderate abilities in terms of comparing, inductive reasoning, deductive reasoning, and inquiry. However, students have low capacity in terms of classifying, analyzing errors, abstracting, analyzing perspectives, making decisions, solving 
problems, investigating, and finding knowledge. This indicates students have low-level thinking skills [19].

Saido, Siraj, Nordin, \& Amedy conducted thinking skills tests on 418 randomly selected Grade VII students in the Iraq-Kurdistan region. The test results showed $79.7 \%$ of students were at the level of Low Order Thinking Skills (LOTS). Low-level thinking skills are more dominated by male students. The results of this study prove that students need to improve higher-order thinking skills, especially in terms of synthesis and evaluation required to increase student creativity in science [20].

Higher-order thinking skills are influenced by several factors, including the way pre-service physics teachers' think and the learning process. Teacher centered learning will make pre-service physics teachers accustomed to being guided in gaining knowledge and not practicing thinking skills to solve problems. As a result, pre-service physics teachers have difficulties when given questions that require complex thinking, which causes low levels of thinking skills. This is consistent with the results of the study Mainali, which states that the success of higher-order thinking skills is found in student-centered learning [21]. Students who are familiar with high-level questions can gain a deeper understanding of a concept [22].

The ability of lecturers also influences the success of the higher-order thinking skills of their students. Lecturers must be able to direct learning, so pre-service physics teachers are trained to solve problems through higher-order thinking skills. Teaching knowledge and competence is very important to ensure the quality of HOTS implementation [23] [24]. Lecturers as facilitators in class must have good pedagogical, professional, social, and personality competencies so that they can carry out learning well.

Pre-service physics teachers' higher-order thinking skills are also analyzed based on each question indicator to find out more specific student skills. The results of the analysis on each indicator are explained as follows:

The indicator analyzes the forces on simple harmonic motion and the quantities that affect it, can be seen in Figure 2.

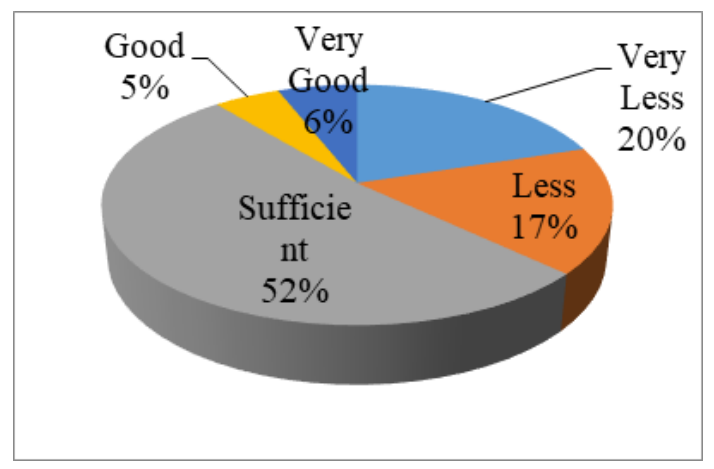

Fig 2. Higher-Order Thinking Skills on Indicator Analyzing Forces in Simple Harmonic Motion and Quantities that Affects It

In this indicator, pre-service physics teachers experience literacy-based learning by reading literature relating to the material to be studied before learning begins. The lecturer tests the literacy skills of preservice physics teachers by asking to mention what they have learned. Besides, the lecturer also asked pre-service physics teacher representatives to demonstrate in front of the class about the concepts of harmonic motion, quantities, and force acting on the simple harmonic motion. This process trains preservice physics teachers' literacy skills through reading and hands-on experience. Rahayuni, Nahdatul, $\& \mathrm{Al}$ stated that there is a relatively strong positive relationship between scientific literacy and higherorder thinking skills, especially in critical thinking skills [25]. This is caused by learning based on scientific literacy, pre-service physics teachers are actively involved in gaining knowledge. Pre-service 
physics teachers are asked to use their expertise to identify problems to find solutions to solve those problems. Pre-service physics teachers who are initially accustomed to lecture learning, must think to solve problems. In this way, pre-service physics teachers are trained to think at a high level.

The indicator determines the period and frequency of vibrations in simple harmonic motion, presented in Figure 3.

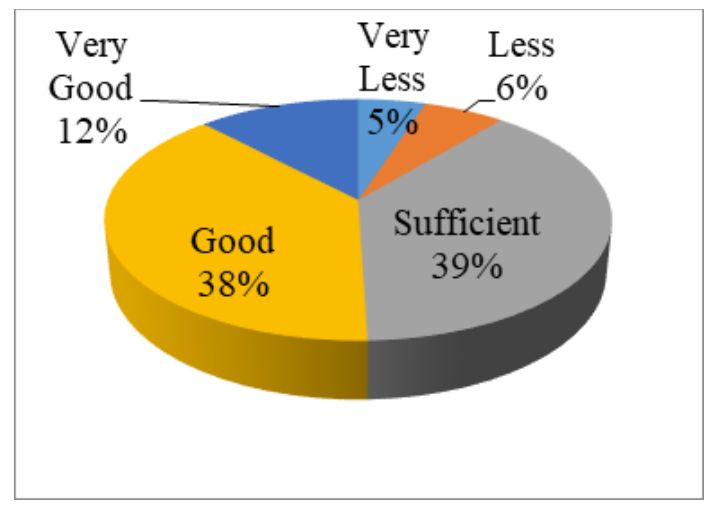

Fig 3. Higher-Order Thinking Skills on Indicator Determines Period and Frequency of Vibrations in Simple Harmonic Motion

The process of scientific literacy in learning this indicator is carried out with pre-service physics teachers being asked to read the material and find the equation of the period and frequency in simple harmonic motion. This scientific literacy process can be said to be successful. It can be seen from the reasonably good thinking skills of pre-service physics teachers on this indicator. This is in accordance with the research results of Susiati et al., which states that there is a positive correlation between scientific literacy and higher-order thinking skills [26].

The indicator determines the equation of deviation in simple harmonic motion and the quantity that affects it, is shown in Figure 4.

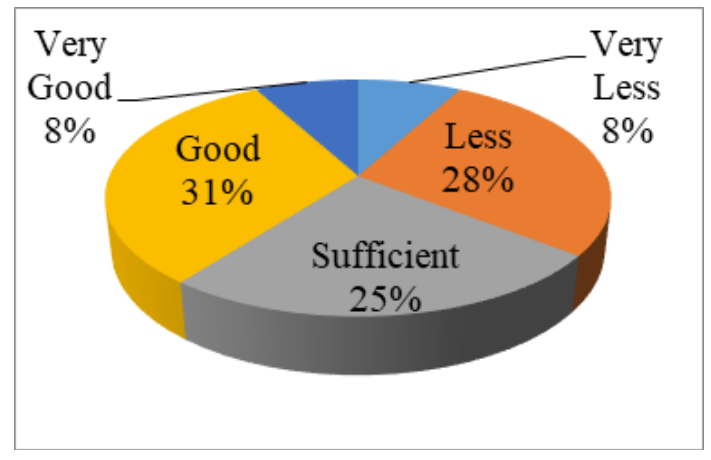

Fig 4. Higher-Order Thinking Skills on Indicator Determines the Equation of Deviation in Simple Harmonic Motion and the Quantity That Affects It

The literacy process carried out in this indicator is that pre-service physics teachers are asked to observe an object that moves harmonically, then find the physical quantities contained in the motion of the object. Pre-service physics teachers are then asked to analyze to find deviation equations in simple harmonic motion. This process trains pre-service physics teachers' thinking skills to solve problems and find a concept from the equation being sought. 
The indicator analyzes the energy in simple harmonic motion, can be seen in Figure 5.

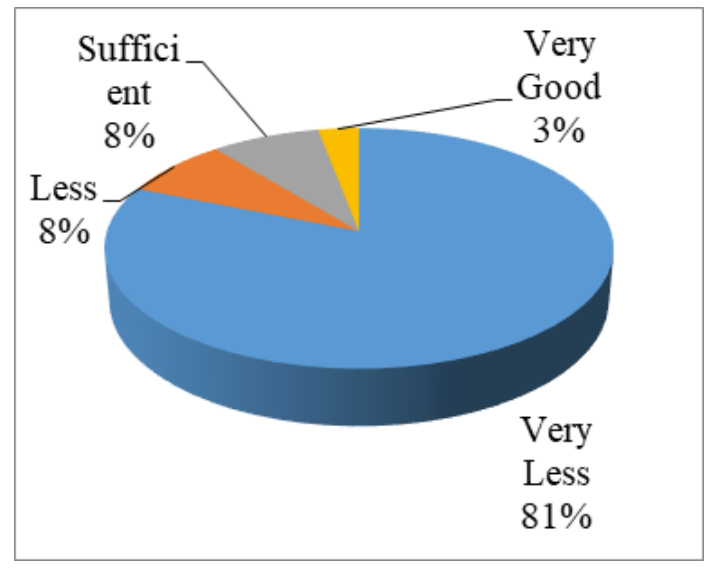

Fig 5. Higher-Order Thinking Skills on Indicator Analyzes the Energy in Simple Harmonic Motion

Pre-service physics teachers' thinking skills on this indicator are still lacking. This is because, during learning, pre-service physics teachers are less actively involved because of the pre-service physics teachers' lack of initial understanding of the material on these indicators. Pre-service physics teachers do not read the material before implementing learning in class. Besides, the calculations that are considered difficult by pre-service physics teachers on this indicator also cause the results of tests of higher-order thinking skills to be low because most pre-service physics teachers do not provide reasons for the answers to this indicator. Research Supeno et al. also show a similar thing; that is students have not been able to provide satisfactory reasons [27].

The results of this research showed a lack of high-level thinking skills of pre-service physics teachers UIN Walisongo Semarang. Pre-service physics teachers will become educators for students when they become teachers. Pre-service physics teachers must master everything needed to prepare to become a teacher.

Higher-order thinking skills of pre-service physics teachers are needed, especially when later they have entered the field as educators. The role of teachers in cultivating higher-order thinking skills is an essential aspect of teaching these skills effectively [28]. Teachers must be able to develop higher-order thinking skills to guide students to find concepts through the learning process.

The ability of a teacher will greatly affect the quality of learning. The success of a lesson depends on how the teacher designs and implements learning in the classroom. Each teacher has a different strategy to apply in learning. However, the strategy applied must refer to the success of the learning objectives. Strategies that can be applied to hone higher-order thinking skills include:

a) The teacher must first introduce to students what higher-order thinking skills are because these thinking skills can be achieved through a process that is not instantaneous. The teacher also needs to explain why students must have these thinking skills. Teachers must be able to make students find strengths and provide challenges to students.

b) The teacher must encourage students to ask a variety of questions. Ideally, the classroom atmosphere is made in such a way that students feel free to ask questions so that students become creative. The teacher can also ask other students to answer questions or lead students to find answers to questions that have been raised. Even so, the teacher must also be able to direct questions that arise from students, which are questions related to the context of the material being discussed in learning.

c) Guide students so that they can relate one concept to another. In this way, the teacher can find out the extent to which students understand a specific concept. Students who have recognized a concept in depth will be able to relate the concept to other concepts in an event related to physics. This method will also deepen students' understanding of a specific concept.

d) Teach students to be able to express opinions, propose hypotheses, and draw conclusions. Teachers 
can lead students through events in everyday life related to the concept of physics. Make it so that students can maximize thinking skills and do not rely solely on explanations from the teacher.

e) Use flow charts or concept maps. The use of concept maps will make students better understand the flow of the concepts being learned. Students will also be able to connect a concept and know the relationship between concepts.

f) Use learning strategies that lead to problem-solving. Teach students the steps to solve a problem so that students can find their concept. Encourage students to solve problems through various methods.

g) Encourage students to think creatively. Teachers need to guide students to find, imagine, and design things they think about. Help students to think out of the box. This way can require creativity from the teacher.

h) When the concepts being learned are complicated and more abstract in nature, invite students to make a mind movie by imagining the conceptual fiction in their mind. This method allows students to visualize and helps students understand concepts in unique ways.

i) Teach students to describe answers. Higher-order thinking skills require students to understand the concept, not just repeating the material that has been taught previously (recall). Students should be encouraged to elaborate on answers to the questions given and explain what has been learned to find concepts.

j) Teach students to make questions and answer connections. This method teaches students to label the types of questions asked, then use the information to formulate answers to these questions. Students must be able to describe responses if the solutions are obtained from books or the internet, or by relying on the knowledge that gained previously. This strategy makes students think at a higher level by connecting what they have already learned with the concepts to be studied.

Lecturers need to make improvements to improve the high-order thinking skills of pre-service physics teachers UIN Walisongo Semarang, especially in the material of Simple Harmonic Motion. Alterations can be made to parts with less high-order thinking skills, that is on the indicators of analyzing the force acting on simple harmonic motion and the quantities that affect it, and analyzing the energy in simple harmonic motion. This is in accordance with the opinion of Benjamin, which states that higher-order thinking skills can be developed through the learning process and experiences obtained from institutions [29]. The follow-up to improve the higher-order thinking skills of pre-service physics teachers can be carried out in courses that will be taken at the next level, namely in the wave course.

Lecturers need to apply various strategies and learning models to improve pre-service physics teachers' higher-order thinking skills. Problem Based Learning is a learning model that can be applied to improve higher-order thinking skills, especially in creative thinking skills [30]. The application of the REACT (Relating, Experiencing, Applying, Cooperating, Transfering) learning model can also train higher order thinking skills. This learning model makes students link learning with everyday life, carry out activities to find and apply concepts, and exchange opinions to solve problems and draw conclusions from the discussions that have been carried out [31]. Efforts to enhance high-order thinking skills also require good cooperation from all lecturers who teach various courses in the Physics Education Study Program of UIN Walisongo Semarang to be able to achieve these goals. This is under the opinion of Abosalem, which states that improving thinking skills requires cooperation between teachers at various learning levels [32].

The lack of higher-order thinking skills of pre-service physics teachers found in this study does not rule out that the higher-order thinking skills of pre-service physics teachers on other materials are also lacking. Therefore, it is necessary to evaluate the higher-order thinking skills of pre-service physics teachers on materials other than simple harmonic motion. The development of pre-service physics teachers 'higher-order thinking skills requires assessment techniques that can help lecturers to identify pre-service physics teachers' thinking skills. Besides, lecturers must apply various assessment methods such as performance-based assessments, and avoid forms of tests that only require knowledge in the realm of memory [33]. 


\section{CONCLUSION AND SUGGESTION}

In general, high order thinking skills of pre-service physics teachers are still in the low category, with an average percentage of achievement of 39\%. The most top thinking skills are found in the indicator determining the period and frequency of vibrations in simple harmonic motion with an average percentage of $60.8 \%$, which is in the good category. The lowest thinking skills are in the indicator of analyzing the energy of simple harmonic motion with an average percentage of $12.8 \%$ with an inferior grade. High order thinking skills on two other indicators, namely analyzing the force acting on simple harmonic motion and the quantity that affects it is in the less category with a percentage of $39.8 \%$; and the indicator determines equation of deviations in simple harmonic motion and the quantity that affects it is in sufficient category with a rate of $48.5 \%$. Lecturers need to follow up to improve pre-service physics teachers' higher order thinking skills, one of which is by implementing learning that is more active in students. Lecturers can also use simulations to improve science process skills, especially higher-order thinking skills. Besides, it is necessary to develop a test instrument to analyze higher order thinking skills in physics material other than simple harmonic motion; so that lecturers can analyze students' higher order thinking skills as a whole.

\section{REFERENCES}

[1] Halim, A., Ngadimin, Soewarno, Sabaruddin, \& Susanna, A. (2018, December). Improvement of high order thinking skill of physics student to prepare human resources in order to faced of global competition in asean economic community. In Journal of Physics: Conference Series (Vol. 1116, No. 3, p. 032009). IOP Publishing.

[2] Istiyono, E. (2017, August). The analysis of senior high school students' physics HOTS in Bantul District measured using PhysReMChoTHOTS. In AIP Conference Proceedings (Vol. 1868, No. 1, p. 070008). AIP Publishing LLC.

[3] Heong, Y. M., Othman, W. B., Yunos, J. B. M., Kiong, T. T., Hassan, R. B., \& Mohamad, M. M. B. (2011). The level of marzano higher order thinking skills among technical education students. International Journal of Social Science and Humanity, 1(2): 121-125.

[4] Zohar, A., Degani, A., \& Vaaknin, E. (2001). Teachers' beliefs about low-achieving students and higher order thinking. Teaching and Teacher Education, 17(4): 469-485.

[5] Ramos, J. L. S., Dolipas, B. B., \& Villamor, B. B. (2013). Higher order thinking skills and academic performance in physics of college students: A regression analysis. International Journal of Innovative Interdisciplinary Research, 4(48-60).

[6] Kurniati, D., Harimukti, R., \& Jamil, N. A. (2016). Kemampuan berpikir tingkat tinggi siswa SMP di Kabupaten Jember dalam menyelesaikan soal berstandar PISA. Jurnal Penelitian dan Evaluasi Pendidikan, 20(2): 142-155.

[7] Zulfiani, Z., Suwarna, I. P., \& Sumantri, M. F. (2020). Science Adaptive Assessment Tool: Kolb's Learning Style Profile and Student's Higher Order Thinking Skill Level. Jurnal Pendidikan IPA Indonesia, 9(2): 194-207.

[8] Batlolona, J. R., \& Mahapoonyanont, N. (2019). Academic Learning Outcome And Creative Thinking Skills On Projectile Motion Topic. JPI (Jurnal Pendidikan Indonesia), 8(1): 1-8.

[9] Supurwoko, C., Sarwanto, S., Fauzi, A., Faradilla, L., \& Dewi, T. S. (2017). Using computer simulation to improve high order thinking skills of physics teacher candidate students in Compton effect. In Journal of Physics: Conference Series (Vol. 909, No. 1, p. 012062).

[10] Wartono, W., Takaria, J., Batlolona, J. R., Grusche, S., Hudha, M. N., \& Jayanti, Y. M. (2018). Inquiry-Discovery Empowering High Order Thinking Skills and Scientific Literacy on Substance Pressure Topic. Jurnal Ilmiah Pendidikan Fisika Al-Biruni, 7(2): 139-151.

[11] PISA. (2006). Assessing Scientific, Reading and Mathematical Literacy. OECD.

[12] Widana, I. W. (2017). Modul penyusunan higher order thingking skill (HOTS). Direktorat Pembinaan Sma Direktorat Jenderal Pendidikan Dasar Dan Menengah Departemen Pendidikan Dan Kebudayaan.

[13] Tiruneh, D. T., De Cock, M., Weldeslassie, A. G., Elen, J., \& Janssen, R. (2017). Measuring critical 
thinking in physics: Development and validation of a critical thinking test in electricity and magnetism. International Journal of Science and Mathematics Education, 15(4): 663-682.

[14] Batlolona, J. R., Diantoro, M., Wartono, \& Latifah, E. (2019). Creative Thinking Skills Students in Physics on Solid Material Elasticity. Journal of Turkish Science Education, 16(1): 48-61.

[15] Gall, M. D., Gall, J. P., \& Borg, W. R. (2003). Educational Research 7th Edition. Pearson Education, Inc, New York.

[16] Purbaningrum, K. A. (2017). Kemampuan berpikir tingkat tinggi siswa smp dalam pemecahan masalah matematika ditinjau dari gaya belajar. JPPM (Jurnal Penelitian dan Pembelajaran Matematika), 10(2): 40-49.

[17] Mohamed, R., \& Lebar, O. (2017). Authentic assessment in assessing higher order thinking skills. International Journal of Academic Research in Business and Social Sciences, 7(2): 466-476.

[18] Serevina, V., Sari, Y. P., \& Maynastiti, D. (2019, April). Developing high order thinking skills (HOTS) assessment instrument for fluid static at senior high school. In Journal of Physics: Conference Series (Vol. 1185, No. 1, p. 012034). IOP Publishing.

[19] Yee, M. H., Jailani, M. Y., Widad, O., Razali, H., Tee, T. K., \& Mohaffyza, M. M. (2015). The effectiveness of higher order thinking skills for generating idea among technical students. Recent Advances in Educational Technologies.

[20] Saido, G. M., Siraj, S., Nordin, A. B. B., \& Al_Amedy, O. S. (2018). Higher order thinking skills among secondary school students in science learning. MOJES: Malaysian Online Journal of Educational Sciences, 3(3): 13-20.

[21] Mainali, B. P. (2012). Higher order thinking in education. Academic Voices: A Multidisciplinary Journal, 2: 5-10.

[22] Jensen, J. L., McDaniel, M. A., Woodard, S. M., \& Kummer, T. A. (2014). Teaching to the test... or testing to teach: Exams requiring higher order thinking skills encourage greater conceptual understanding. Educational Psychology Review, 26(2): 307-329.

[23] Sulaiman, T., Muniyan, V., Madhvan, D., Hasan, R., Syrene, S., \& Rahim, A. (2017). Implementation of higher order thinking skills in teaching of science: A case study in Malaysia. International research journal of education and sciences (IRJES), 1(1): 2550-2158.

[24] Zohar, A. (2004). Teachers' metacognitive declarative knowledge and the teaching of higher order thinking. In Higher Order Thinking in Science Classrooms: Students' Learning and Teachers' Professional Development (pp. 177-196). Springer, Dordrecht.

[25] Rahayuni, G. (2016). Hubungan keterampilan berpikir kritis dan literasi sains pada pembelajaran IPA terpadu dengan model PBM dan STM. Jurnal penelitian dan Pembelajaran IPA, 2(2): 131146.

[26] Susiati, A., \& Miarsyah, M. (2018). Hubungan Kemampuan Membaca Pemahaman dan Kemampuan Berpikir Tingkat Tinggi dengan Kemampuan Literasi Sains Guru Biologi. Biosfer: Jurnal Pendidikan Biologi, 11(1): 1-12.

[27] Supeno, S., Astutik, S., Bektiarso, S., Lesmono, A. D., \& Nuraini, L. (2019, March). What can students show about higher order thinking skills in physics learning?. In IOP Conference Series: Earth and Environmental Science (Vol. 243, No. 1, p. 012127). IOP Publishing.

[28] Yen, T. S., \& Halili, S. H. (2015). Effective teaching of higher order thinking (HOT) in education. The Online Journal of Distance Education and e-Learning, 3(2): 41-47.

[29] Benjamin, R. (2008). The case for comparative institutional assessment of higher-order thinking skills. Change: The Magazine of Higher Learning, 40(6): 50-55.

[30] Wartono, W., Diantoro, M., \& Bartlolona, J. R. (2018). Influence of problem based learning model on student creative thinking on elasticity topics a material. Jurnal Pendidikan Fisika Indonesia, 14(1): 32-39.

[31] Rosdianto, H., Syahandri, U. H., \& Mahapoonyanont, N. (2020). Students' Cognitive Learning Outcomes In Simple Machine Subjects Through REACT Learning Model. JIPF (Jurnal Ilmu Pendidikan Fisika), 5(3): 123-131.

[32] Abosalem, Y. (2016). Assessment techniques and students' higher-order thinking skills. International Journal of Secondary Education, 4(1): 1.

[33] Doganay, A., \& Bal, A. P. (2010). The Measurement of Students' Achievement in Teaching Primary School Fifth Year Mathematics Classes. Educational Sciences: Theory and Practice, 10(1): 199-215. 